\title{
LABOUR PRODUCTIVITY IMPROVEMENT MODEL
}

\author{
Ramjee Prasad Paudyal ${ }^{*}$
}

\begin{abstract}
Majority of the share investment in the enterprises are initiated by the Government of Nepal. This study has considered productivity model developed the Sumanth (1984). Accordingly, some of the variables are identified for the productivity improvement like: productivity planning, improvement, measurement, and evaluation. The basic objective of the study is to assess the labour productivity of the manufacturing public enterprises in Nepal. This study reveals that the concept of productivity and its benefits to investors, employees, government, society and the enterprises themselves, were not properly understood and realized by the employees of the enterprises. The managers were also doubtful about the effectiveness of the existing personnel policies. The major problems associated with productivity improvement were found to be under utilization of production capacity and poor maintenance of machines. Similarly socio-cultural contexts like favoritism, nepotism, and corruption had seriously influenced the appraisal practices, and the productivity status. The productivity was also suffered because of the failure of the management to adjust to the changes taking place within the workforce. In managing human resources, leadership styles and motivational systems had not kept abreast of these changes.
\end{abstract}

Key words: productivity, awareness, favoritisms, employees, government, literacy campaigns.

\section{INTRODUCTION}

In this age of globalization, business organizations are rapidly spreading as multinational organizations throughout the globe giving tremendous growth of competition. Competition among the business units is not only confined to grab larger market shares, but also for acquiring resources. With the growing thrust of globalization and increasing competition among the economic units for both inputs and outputs, the world in the twentieth century was also witnessed the unprecedented concern of the people and societies for the optimization of limited resources. In this context the utmost concern of business units should be competitive.

Productivity is a multi-dimensional concept related to better income for investors, better wages and bonus for the individual workers, more taxes and revenues for the government, and easy access to goods and services for the society. The significance of the concept of productivity was recognized in the early seventeenth century, however it got its real importance during twentieth century. The determinants of productivity were free global market, international competition, and rising social and legal pressures for the productive use of resources. Hence, productivity gets top priority in every society both at macro as well as micro levels.

Dr. Paudyal is an Associate Professor at Public Youth Campus, T.U., Kathmandu, Nepal. 
The manufacturing public enterprises in Nepal are realizing the significance of enhancing labour productivity with the emerging environment of competition, liberalization and deregulation. The ever-growing process of globalization, the opendoor policy of imports, and the obvious shift to buyer's market have created new demands and challenges. These opportunities along with challenges have created a situation to match markets with products and other corporate resources more effectively and efficiently to strengthen their competitive capacities.

After the restoration of multiparty democracy in 1990, the issue of productivity has got higher priority at the national level. In 1993, NPEDC was established. Similarly, Nepal Productivity Council (NPC) was formed in 1996. Similarly the Ninth plan (1997-2002) which had aimed poverty alleviation, had incorporated "productivity promotion and quality management" as one of the main thrust area of national development.

The productivity movement of Nepal begins together with the establishments of the Asian Productivity Organization (APO) in 1961 A.D. in international context. Nepal is founding member of this organization. Nepal's growing participation, commitment and membership in different forums of international and regional communities, including the WTO, have brought new threats and opportunities in Nepalese enterprises in the global market. During the courses of globalization major shifts were made in industrial, trade, labour and foreign investment policies. These reforms along with fiscal reforms and structural adjustments were introduced to reduce unproductive controls to enhance productivity, to attract foreign investment, to strengthen private investment, and an integrate of the national economy into global market.

In general, labour productivity refers the quantity of output produced by a given quantity of labour input. The labour is considered to be a key determinant of total value added. More precisely labour productivity is often used as a factor of industrial efficiency. Labour productivity is, therefore, concerned with the efficient use of labour, so that optimum outputs and benefits could be achieved.

In the context of the emerging business reality of this study has been undertaken to understand and analyze the emerging issues of labour productivity, and productivity measurement, improvement, planning and evaluation. The measurement models developed by Shimizu et al. (1997), Prokopenko (1989), and Sumanth (1984) are used in the study to assess and analyze the productivity situation in the selected manufacturing public enterprises.

\section{ISSUES}

This study has been undertaken to address the following issues:

- What is the awareness of employees in the enterprises about productivity and benefits?

- What are the critical factors significantly influencing labour productivity?

\section{OBJECTIVES OF THE STUDY}

The basic objective of the study is to assess the labour productivity of the manufacturing public enterprises in Nepal. The specific objectives are as follows:

(1) To study the level of productivity awareness among employees, 
(2) To assess the factors affecting the implementation of labour productivity programs, and

(3) To suggest recommendations for the improvement of labour.

\section{RESEARCH DESIGN AND METHODOLOGY}

The officer-level employees of six enterprises the main sources of primary data and information were. Altogether six manufacturing public enterprises were selected in the study: Dairy Development Corporation, Hetauda Cement Factory, Herbs Processing and Production Company, Janakpur Cigarette Factory, Lumbini Sugar Mill and Royal Drugs Limited. Questionnaires and indepth interviews were the basic research instruments used to collect primary data.

Four different types of measures were used to get an overview of productivity in the selected enterprises. First, outcome measures were studied to assess the outcomes and their influence in productivity. Secondly, input measures measured the inputs in the production processes. This measure was compared to outputs to measure productivity. Thirdly, action measures were studied to assess the activities that affected the desired productivity. Finally, the diagnostic measures for output, input, or action measure is at its current level. A measurement regime based solely on input or output measure is unlikely to be of strategic benefit.

In the context of emerging business reality, present study has been undertaken to understand and analyze the emerging issues in labour productivity, and productivity measurement, improvement, planning and evaluation. The measurement model developed by Sumanth (1984) has been applied in the study to assess and analyze the productivity situation in the selected manufacturing public enterprises.

The senior executives and managers of the selected manufacturing public enterprises were considered for in-depth interviews. These senior managers were selected irrespective of their nature of job and tenure of employment. In the process of selecting senior managers for the in-depth interviews, due attention was given to the representation of major departments/divisions of the enterprises including technical and non-technical personnel based on their population. The total senior managers in the enterprises selected for in-depth interviews were 20. All the managers heading the major departments in these enterprises were included in the sample as they were supposed to have greater insights into the issues and could provide reliable and valid information.

The collected information was then analyzed respondent-wise and enterprises-wise. The responses were also analyzed based on the nature of jobs (technical and non-technical) and respondents' age and experiences. The primary data was analyzed following the computer software program EPI info 6- version 6.02, October 1994- World Health Organization, Center for Disease Control and Prevention, USA

Since, the framework of analysis included empirical study and analysis of opinions pertaining to various issues related to labour productivity. This study is mainly descriptive-cum-exploratory in nature. 


\section{Productivity CyCle System Model}

When the countries have to improve their national productivity levels and growth rates, first effort must be at the organizational level. Such efforts need to be formal in order to be successful and effective. A formal productivity program in an organization is generally called the productivity cycle. In this study, the analysis of the manufacturing public enterprises in Nepal has been done based on the productivity cycle system model as suggested by Sumanth (1984).

An organization which begins with a formal productivity program for the first time can begin with productivity measurement. Once the productivity levels are measured, they have to be evaluated or compared against planned values. Based on this evaluation, target levels of productivity are planned on both short term and long term basis. In order to assess the degree to which the improvement will take place next period, productivity levels must be measured again. This cycle thus continues as long as the productivity program operates in the organization (Sumanth, 1984).

Table 1: Productivity Cycle System Model

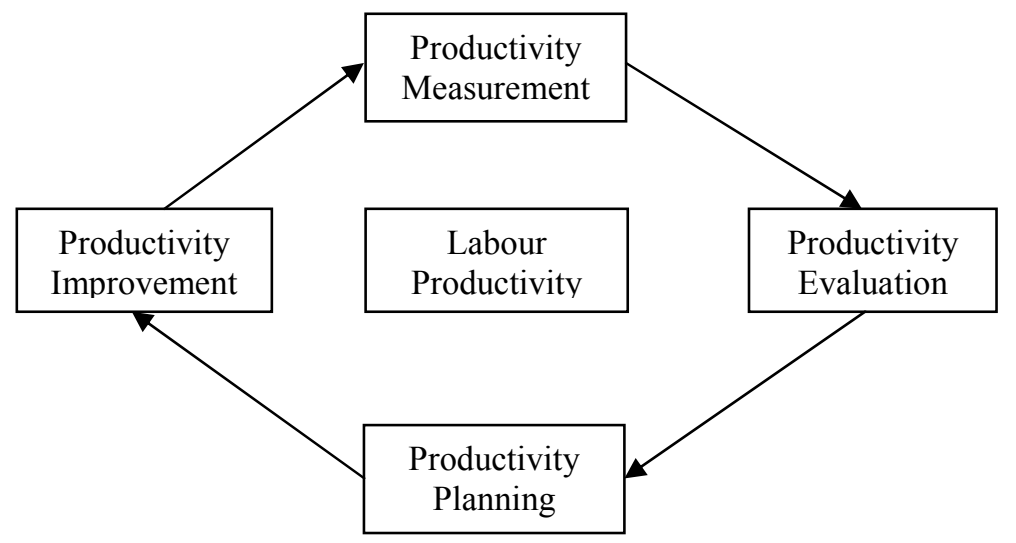

Source: Sumanth (1984).

\section{FINDINGS}

The major findings are organized into different issues like productivity awareness, planning, improvement, implementation, measurement, accountability of the government and the like.

\section{Awareness}

Though the respondents were found to be in favor of labour productivity, they were confused about the concepts of productivity. The technicians were better aware of productivity related concepts than their counterparts nontechnicians. All the respondents opined that the employees need to be articulated to productivity related concepts and benefits. The respondents suggested some issues to be fairly addressed by the management. These were productivity plan formulation and implementation, productivity measurement, cost reduction programs, and information-sharing. These activities would give positive results if they were undertaken with the involvement of employees. 
The concept of productivity and its benefits to investors, employees, government, society and the enterprises themselves were not properly understood and realized by the employees of the enterprises. They had no idea about it. Certain changes were made in their enterprises due to the introduction of new technology and the changes made in the top management. In spite of these changes, there was hardly any change in their productivity position.

\section{PlanNing}

Without appropriate rules and standards, productivity planning cannot be effective. At the policy level, however, differences need to be made with respect to rule formulation based on the nature of the industry. The workers should be identified as vital among the resources for the improvement of labour productivity. However, the employee-related priorities were different and mixed in the enterprises under study. The top-level executives had paid only moderate attention to labour productivity planning. Their focus was just to minimize the impact arising due to excessive political interferences. Hence, less attention was paid to the introduction of new technology, as it demanded higher investment and additional workforce. Further, the managers were also doubtful about the effectiveness of the existing personnel policies to enhance labour productivity.

\section{IMPROVEMENT}

The system of productivity competition and reward was not properly used by the enterprises. Similarly, there was also no system of punishment. Thus, the basic pillars of building the productivity environment did not exist in the enterprises. Jobs were created without considering the labour and other costs. The staff members were not involved in the productivity improvement programs. Their opinions were not sought. Tasks were not assigned to employees according to their interests, education or experience. These practices had serious implications on workers' commitment to productivity. The technicians were found to be relatively more aware and committed to productivity.

The productivity improvement strategies were not exercised and formalized by the enterprises. However, the enterprises exercised activities like setting specific objectives for work, fixing production targets, undertaking performance evaluation, associating the related staff to specify the target dates, saving costs, minimizing wastages, encouraging suggestion from employees, and making provisions for skill development of employees.

The major problems associated with productivity improvement were: utilization of under capacity, poor maintenance of machines, lack of raw materials, less working hours, failure of prompt delivery of the goods to the customers in time, higher energy and fuel wastages, and excessive scrap and material wastages.

\section{PRODUCTIVITY IMPLEMENTATION}

The effective implementation of the productivity plans generally rests on the people. The prime responsibility should be rest on the senior executives of their enterprises for implementing the productivity programs; followed by departmental heads and technical engineers. At the same time, they also agreed that the responsibility of increasing productivity rests with all the employees right from the top executives down to the lower level workers. 


\section{MEASUREMENT AND EVALUATION}

The decision making pattern of management was the most influencing factor whereas the attitude of the workers was the least influencing factor. The quality of labour, freedom of work, better utilization of existing talents, quality of raw materials, appropriate technology, information management system, and freedom of expression were the other critical factors leading to productivity in the enterprises.

An evaluation system has both the administrative and developmental objectives. Administrative objectives refer the use of system for such decisions as promotion, placement, continuation of service and so on. Developmental objectives pertain to the use of the system for identification of strengths and weaknesses. The present evaluation and measurement systems restrict promotion and also hinder employees' commitment to productivity.

The next aspect preferred by the employees was the feed-back system of the evaluation. In fact, there was a need to bring about changes in the personnel policies of the enterprises. The respondents emphasized to improve productivity, the evaluation results should be communicated to them and their strengths and weaknesses should be identified to them for future improvement. The qualification and experience were the main bases of the existing system of evaluation for promotion. The majority of the respondents clearly expressed that there was hardly any provision for learning attitudes and creativity in the evaluation system. Similarly, the enterprises also seriously lacked in creating proper work environment and involving employees in problem-solving.

The respondents had opposed the inextricable components of the evaluation system currently in use for various reasons. One of the deterrent points of the system was the influence of the socio-cultural context. The respondents confessed that the socio-cultural contexts like favoritism, nepotism, and corruption had seriously influenced the appraisal practices. Such types of practices frustrate the employees and affect their productivity.

\section{MANAGERIAL ATTITUde AND GovernMent SUPPORT}

The productivity-focused schemes adopted by the enterprises were not satisfactory because of the following reasons:

- $\quad$ There was no formal productivity planning, hence the employees were less aware about the productivity status of their enterprises.

- There was the absence of productivity training and education to employees.

- $\quad$ The productivity status was seldom rechecked and evaluated.

Despite these shortcomings in the productivity-related activities, the respondents appreciated the efforts made by the management to enhance productivity. Factors like the positive managerial thinking and attitude, positive thinking of the employees, attitude and abilities of the supervisors, quality of employees in terms of skills, and availability of tools and equipment had led to build the strengths of the public enterprises. However, these strengths were not effectively been used to develop their productivity and competitiveness. 
With respect to the possible government support, introduction of the productivity education initiated by the universities in Nepal at different levels was highly commended as the most sustainable and long-term initiatives to improve labour productivity. The government should pay more attention on publish materials related to productivity, start the literacy campaigns in various enterprises targeting the shop-floor workers, establish a separate commission to oversee the emerging productivity-related issues, and formulation and execution of the rules and regulations favorable to productivity.

\section{Critical Factors AfFecting Labour Productivity}

All the manufacturing public enterprises under study were running with big losses due to their poor performances. The personnel expenses occupied a huge portion of the operating expenses and the income generated by the employees did not cover their own expenses. The value added output generation was also low as compared to the expenses. That is why labour productivity status in financial terms was not satisfactory. This fairly indicates the need to strengthen the factors directly influencing labour productivity in the enterprises.

The factors negatively influencing labour productivity were lack of manpower planning, lack of skilled manpower, lack of technical manpower, ineffective role of trade unions, role of improper execution of the Trade Union Act, and weak employers' associations. Particularly, labour productivity was affected the most by the lack of manpower planning (DDC and HPP), the lack of skilled and technical manpower (JCF), and the lack of capable managerial staff (HCF, RDL and LSM).

\section{CONCLUSION}

The enterprises share certain constraints such as capital, production process, technology, energy, information and public policies, the variables in the productivity equation would be different for each of them. These variables can be defined in terms of policies, strategies, human resources and their motivation, work culture, participative climate, and so on. The variables in the productivity equation are difficult to quantify. Each individual enterprise must therefore develop its own equation for enhancing productivity, which is specifically tailored to its products, markets, technologies, and work force.

Nepal is a member of the World Trade Organization. Nepalese enterprises should strive to remain competitive under a liberalized regime. These enterprises need to properly identify and use the components of the productivity equation to enhance their competitive postures. This is the only way for the manufacturing public enterprises to remain sustainable. The public enterprises should understand that competitive advantage can be built and sustained around six components: low cost, quality, innovation, information, technological adaptation and change. The success of this transformation depends on employees who can work in teams, make decisions, and solve problems.

Public policy, and quality of management and unions are important factors for enhancing productivity. An increase, for example, in participation, gain-sharing, industrial peace, and capacity utilization might create proper conditions for total productivity increments in the future. Enhanced worker 
awareness, information-sharing, and workers' participation can thus be predicted to have positive effects on productivity. Hence the dynamics of productivity were found to be influenced by many factors and variables.

The perceived work environment does make a difference in the level of productivity in enterprises. Managers at all the levels should thus pay attention not only to input-output equations of productivity, but also to the work systems, processes and environments. Several positive aspects were perceived as existing broadly across the enterprises like positive attitudes, target-setting practices, process reviews, reward, gain-sharing, and team activities. However, lack of proper evaluation system undermines these initiatives of management and employees and ultimately affects productivity. The role of managers are vital, particularly in the areas of goal clarity, open interaction, supervisory support for the teamwork.

Rigid and formal management structure and conservatism existing in the enterprises impede productivity, because the employees are likely to perceive each of these factors as controlling. The enterprises use a limited range of human resource tools to identify and support productivity through recruitment, training and performance management.

In managing human resources, leadership styles and motivational systems had not kept abreast of these changes. Furthermore, the managers had neglected to improve and monitor employee productivity and taking corrective actions. Management's ability to take corrective action had been frustrated by the success of employees in having such actions reversed through union actions and court litigation.

\section{WORKS CITED}

Adachi, J. (1999). Productivity and Development. Vol. 4, No. 3, NPEDC, Kathmandu.

APO (2001). Asia pacific productivity data and analysis. APO, Tokyo.

Japanese Productivity Council (1988). Introduction to the roles of Productivity facilitators. Overseas Technical Cooperation Department. JPC, Tokyo, Japan.

National Planning Commission (1998). Approach to Ninth Plan (1997-2002). GN, Kathmandu.

Ninth plan (1997-2002). Planning Commission. GN, Kathmandu.

Prokopenko, J. (1987). Productivity management: A practical handbook. ILO, Geneva.

Shimizu, M., Wainai, K., and Avedillo-Cruz, E. (1997). Value added productivity measurement and its practical applications. Japan Productivity Centre for Socio-Economic Development (JPC-SED), Tokyo.

Sumanth, D.J. (1984). Productivity engineering and management. Mc-Graw Hill Book Company, New York.

World Health Organization (1994). EPI. Info 6-Version 6.02. USA. 